\title{
BEYOND TOM AND TOVE \\ Queering Finnish Museums from an Intersectional Perspective
}

Rita Paqualén

\section{ABSTRACT}

In this text, I will discuss the current interest in LGBTQ issues within the Finnish museum sector and suggest ways to address LGBTQ+ pasts from an intersectional perspective. I will start with a small detour into my own early experience of working in a museum, and then continue with a discussion on the history of queering museums in Finland and the projects Queering the Museums (2012-2014), Finland 100 - In Rainbow Colours (2016-2018), and Queer History Month in Finland (2018-). I end my article by suggesting that we, as researchers and professionals within memory institutions, need to pay more attention to what versions of LGBTQ history we are (re)producing and (re) presenting, and to what kinds of stories we collect and how.

\section{ABSTRAKTI}

Tässä esseessä keskustelen suomalaisen museokentän ajankohtaisesta kiinnostuksesta LHBTIQ+ kysymyksiä kohtaan, ja ehdotan tapoja, joilla käsitellä LHBTIQ+ vaiheita intersektionaalisesta näkökulmasta. Aloitan pienellä sivupolulla varhaisiin kokemuksiini museotyöstä, jatkan suomalaisten museoiden pervouttamisen historiaan ja kerron Queering the Museums (2012-2014) ja Suomi 100 - Sateenkaaren väreissä (2016-2018) -hankkeista sekä Sateenkaarihistoriakuukauden vietosta Suomessa (2018-). Lopetan artikkelini ehdotukseen, jonka mukaan meidän - tutkijoiden ja museoalan ammattilaisten - tulisi kiinnittää enemmän huomiota siihen, millaisia versioita sateenkaarihistoriasta tuotamme ja esitämme ja minkälaisia tarinoita keräämme ja miten.
In this commentary, I will discuss the current interest in LGBTQ issues within the Finnish museum sector and suggest ways to address LGBTQ+ pasts from an intersectional perspective. I will start with a small detour into my own early experience of working in a museum, and then continue with a discussion of the history of queering museums in Finland and the projects Queering the Museums (2012-2014), Finland 100 - In Rainbow Colours (2016-2018), and Queer History Month in Finland (2018-), in which I have been involved.

\section{The Secret Past of Tammisaari}

During my final years at high school, I worked as a museum guard and guide at the local museum in a Finnish coastal town called Tammisaari (in Swedish: Ekenäs). It was a small museum with some historical buildings and a museum hall, which during those years showed mainly art exhibitions. The museum did not yet have a museum shop nor a cafeteria, but it sold cards from earlier exhibitions in a small rack. One of these cards was a photo from the 1890s depicting a woman in a boat with the characteristic skyline of Tammisaari in the background. [Fig. 1.] I would look at the card during slow hours while waiting for customers to come, but never really payed attention to it or turned it over to find out who had taken it. 


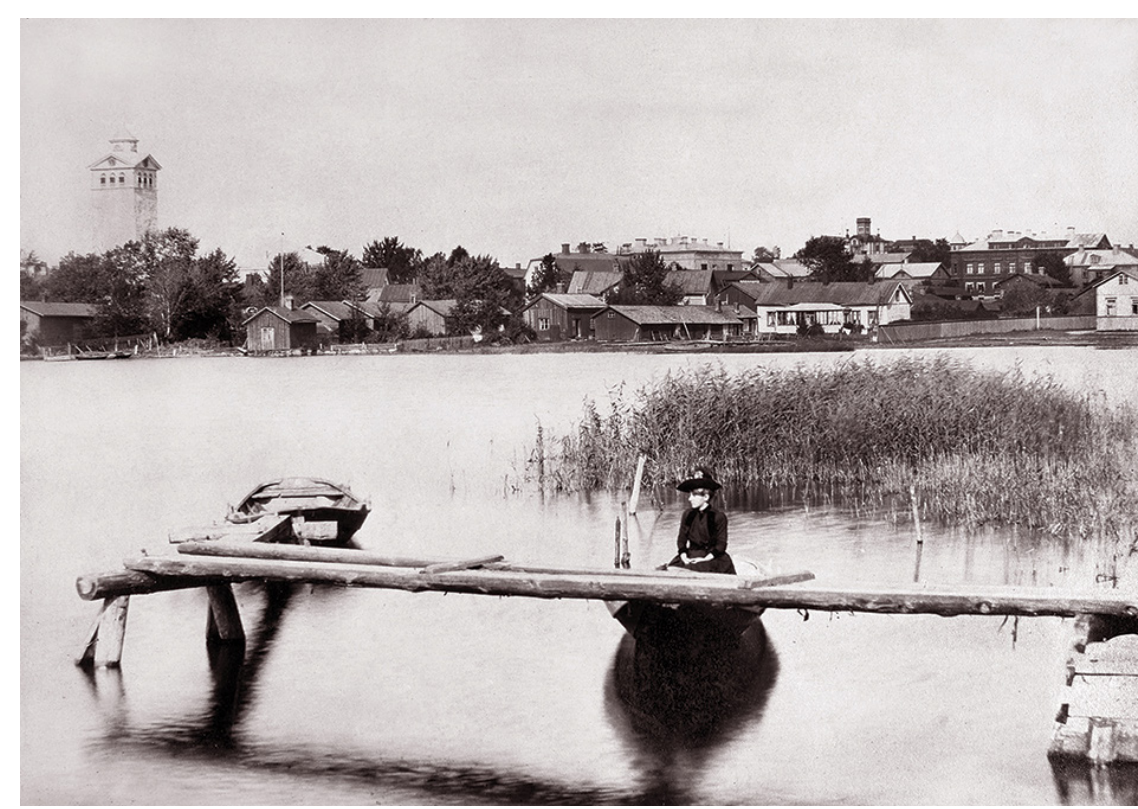

Fig. 1. The South bay of Tammisaari. Photo Marie Høeg. The Raasepori museum collection.

Growing up in Tammisaari as a teenager in the 1980s was a suffocating experience - the town felt small and narrow minded. Queer presents or pasts were never discussed in my school or elsewhere, closets were firmly shut, and it was as if queers had never lived in this outwardly idyllic, yet secretly inhospitable, coastal town.

The postcard tells another story. Had I turned it over, I would have learned that it was taken by the Norwegian photographer Marie Høeg (1866-1949), who came to Tammisaari and opened her first photo studio there in 1888. [Fig. 2.] Hers was the first professional photo studio in the town, and in 1893 she opened another in the nearby town of Hanko. In 1895, she moved back to Horten in Norway, where she opened a studio with her "friend" Bolette Berg (1872-1944) and later became one of the pioneers of the Norwegian women's movement (Stuksrud 2009, 2; Lindqvist 2018, 11).

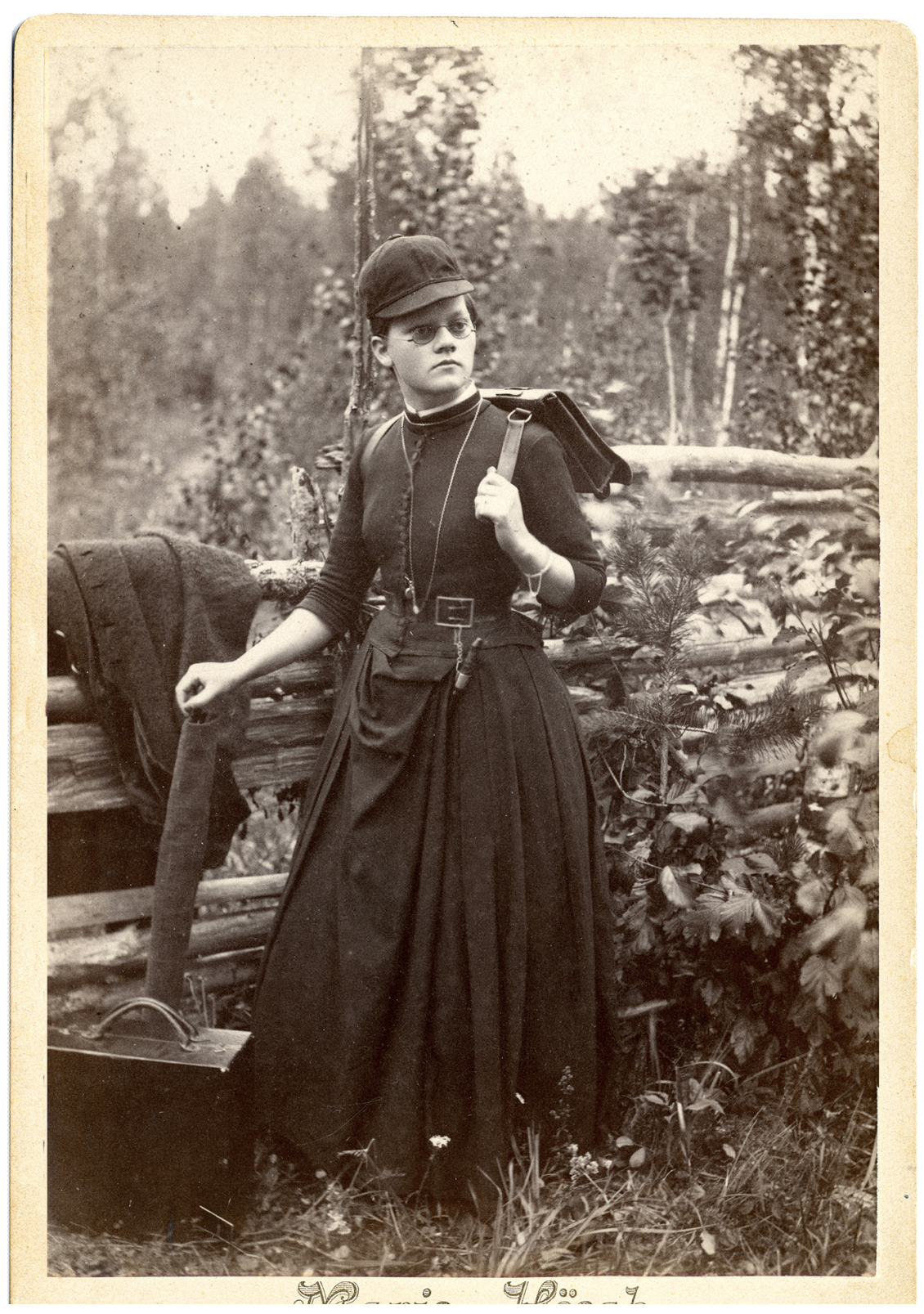

Fig. 2. Self portrait of Marie Høeg around 1890. Photo Marie Høeg. The Raasepori museum collection.
SQS

$1-2 / 2020$

63

Queer Mirror

Discussions 
This could have remained the official story of Marie Høeg, had it not been for the archival discovery made by the Preus Museum in Horten in the 1980s, when a small box labelled "private" was opened in her archive. The box contained 40 glass negatives from the turn of the century, ca. 1895-1903. These images opened up a very different reading of her and Bolette's relationship and of Høeg's life and work, but they might also tell us something about the queer past of Tammisaari. [Fig. 3-5.]
The pictures are playfully queer and subversive, quite different from the studio portraits and pictures of landscapes and buildings owned by the museum in Tammisaari. The private pictures portray Marie, Bolette, and their friends playing with and transgressing the socially accepted gender roles of the time. In the pictures we see an androgynous Marie with her hair cut short and a cigarette in her mouth, with a moustache and crossdressing as a man, and in one picture we see her in drag arm in arm with a female

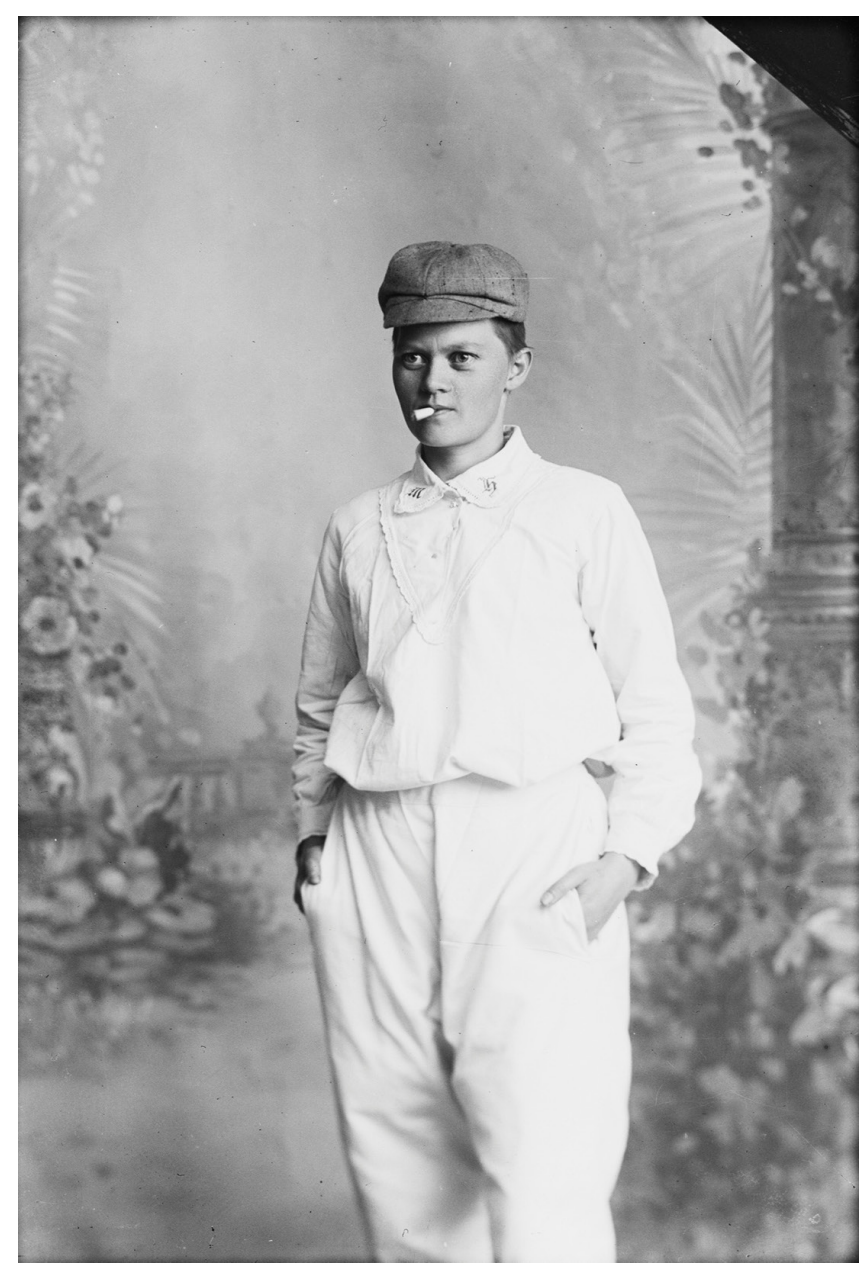

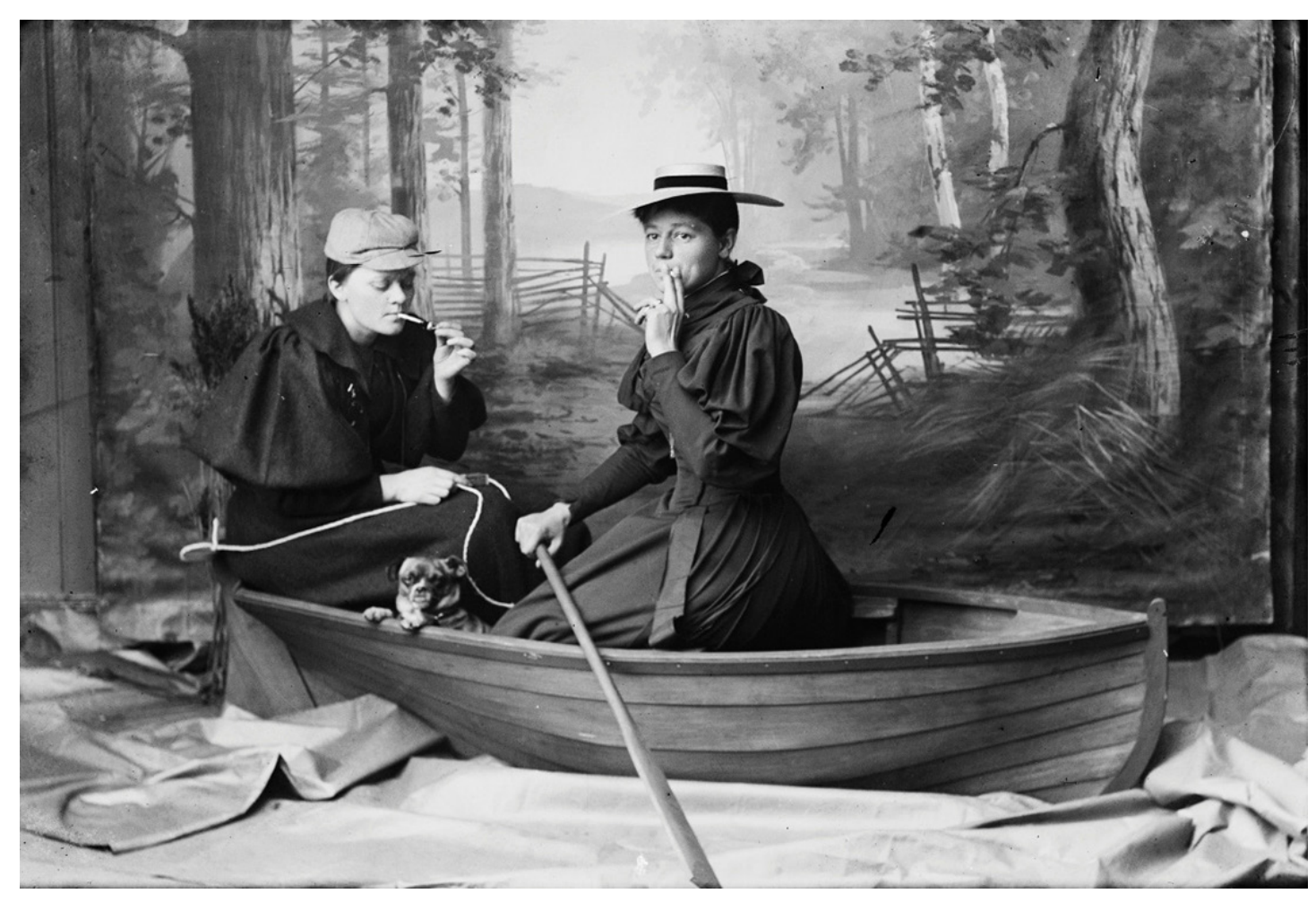

Fig. 3 (left). Marie Høeg as a young boy with cigarette. Photo: Berg \& Høeg, ca. 1895-1903. The Preus museum collection. Fig. 4. (above). Photo Berg \& Høeg, ca. 1895-1903. The Preus museum collection.
SQS

$1-2 / 2020$

64

Queer Mirror

Discussions 


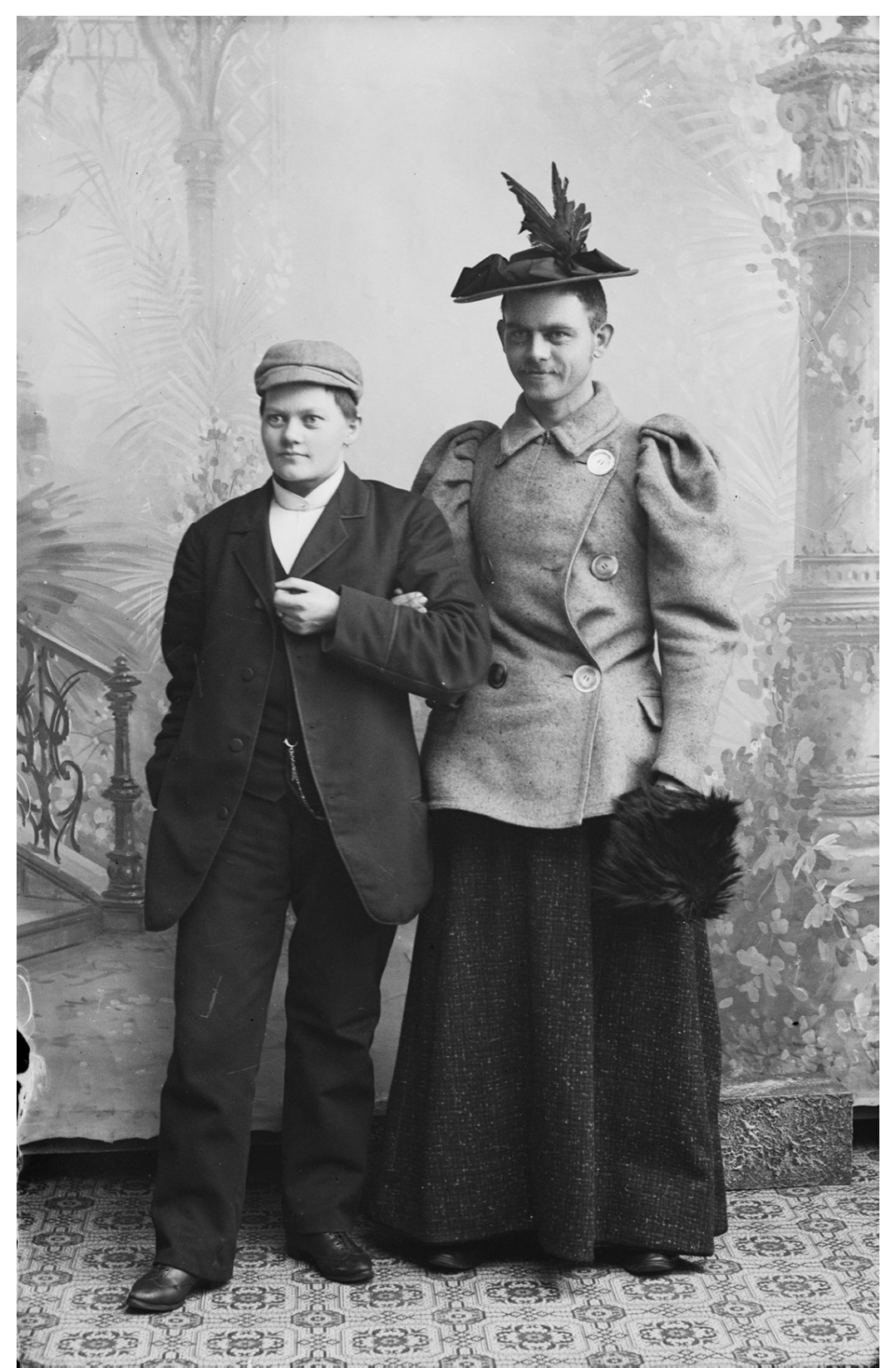

Fig. 5. Marie Høeg posing with an unknown male in the studio. Photo: Berg \& Høeg, ca. 1895-1903. The Preus museum collection. impersonator. We see Marie and Bolette sitting in their living room, posing in a boat as a "butch-femme" couple, or playing cards, drinking alcohol, and smoking cigarettes with their friends. The pictures, now around 120 years old, still have a very contemporary feel.

Besides these pictures, there is very little information on the private life of Marie Høeg and Bolette Berg, and no personal records that would tell us anything about the nature of their relationship. Nor do we know what brought Marie Høeg to Tammisaari in the first place. We can only guess, and through these guesses maybe find some clues to the queer past of the town.

One piece of context that might be useful for understanding Marie Høeg's life is the Swedish-speaking teachers' college for women, Ekenäs seminarium, which had opened its doors in Tammisaari in 1871. The teachers' training school was one of the few colleges that were open to women at the time. Many of the Swedish-speaking pioneers of the women's movement in Finland had studied in Tammisaari, and some of them, like for example Vera Hjelt (1857-1947), formed all-female communities and lived in same-sex relationships (Wikander $2018,105,121 \mathrm{ff})$.

Since Marie Høeg lived in Tammisaari for six years, it is probable that she befriended students of the college, most of whom were, like her, newcomers without family ties in the small town. According to the local contemporary photographer Vidar Lindqvist, who has been a collector of her photographs, Høeg often used students of the college as models in her pictures, including the postcard mentioned earlier. The composition of a young woman in the centre of a landscape is typical for Marie Høeg, as Vidar Lindqvist's private collection of her photographs from Tammisaari attests. ${ }^{1}$

1 Vidar Lindqvist in an interview in his home in Tammisaari 13.3.2020. Most of the pictures in his private collection are printed in his book Ekenäs (2018). 
These staged photographs, some of some of which were also sold as postcards in her studio, are interesting in the context of her later private images. Even if many of her early commercial works are rather traditional, she nevertheless left small, subversive traces of herself in her pictures that can introduce new readings of the history of Tammisaari.

\section{Queering Finnish Museums: A Short History}

When the newly found photos by Marie Høeg were displayed at the museum in Horten, and later in Tammisaari, her relationship with Bolette Berg was described as follows in the exhibition catalogue Marie Høegkvinnesaksaktivist, organisator ogfotograf (1996): "Marie Høeg and Bolette Berg were together throughout their lives" (Moksnes, 1996:8). Beyond the quotation above, the catalogue did not discuss her personal relationship with Berg. Høeg's playful and genderqueer photographs and self-portraits were only briefly described as an expression her "drive, intelligence and fighting spirit” (Moksnes, 1996:17).

Although Marie Høeg's self-portraits and other genderqueer photographs were included in the 1996 catalogue, they were not put into an LGBTQ historical or queer art historical context. In the framework of the catalogue, the pictures become an expression - or an extension - of her women's rights activism, rather than an expression of an LGBTQ identity or a queer play on gender and sexual norms. The time was not yet ripe for that kind of a reading and (re)presentation.

LGBTQ history, memories, and culture were not embraced as topics for Finnish museums in the 1990's, although some art museums in the late 1990s and early 2000s started to exhibit explicitly queer or gay art. Some such exhibitions included the art of Robert Mapplethorpe (Turku Art Museum 1993), Tom of Finland (Jyväskylä Art Museum 1999),
Pierre \& Giles (Turku Art Museum 1999-2000), and Kalervo Palsa (Kiasma 2002), as well as the much-debated exhibition Ecce Homo by the Swedish photographer Elisabeth Ohlson Wallin (The Finnish Museum of Photography 2000). It was not until the new millennium that LGBTQ history became a major subject in Finnish history and cultural history museums, and when it did it was as a result of initiatives within the queer community.

The first museum to take on LGBTQ history as a subject was the publicly funded Finnish Labour Museum Werstas located in Tampere. It all started in 2002, when the researcher Tuula Juvonen contacted the museum director Pontus Blomster and suggested "that Werstas would start, as the first and only museum in Finland, to collect materials about LGBT lives" (Juvonen 2018 [2012], 24f). Juvonen managed to convince Blomster of the idea, and he also got the Finnish Labour Archives in Helsinki interested in the project. They began collecting LGBTQ materials and items in 2002, in cooperation with local - and later also national - LGBTQ organisations. (ibid.) Today, Werstas, as one of seventeen special museums in Finland, has an assigned national responsibility to collect labour and social history - and, as part of the latter, LGBTQ history - whereas the Labour Archive has become the archival repository for many LGBTQ organisations.

The first exhibition on queer history in Finland was a small show called Vaarin paketti ja sateenkaarinappi (Grandpa's parcel and the rainbow badge), arranged by Werstas in 2005 . The exhibition was the result of an initiative by the artist Raini Vallinharju, and it was linked to the new collecting policies of the museum. Its aim was "to raise awareness about the current lack of knowledge about Finnish LGBT history and hence the importance of new donations" (Juvonen 2012[2018], 25). A small booklet, Vaarin paketti ja sateenkaarinappi (2005), was also printed for the exhibition to introduce Finnish LGBTQ history and explain collection 
practices. In 2013, the museum showcased its first large exhibition on the history of the LGBTQ movement, Delight and prejudice (Hilpeys ja ennakkoluulo).

The first major exhibition on LGBTQ history in Finland, Rainbow-Finland (Sateenkaari-Suomi), took place at the Vantaa City Museum in 2007, six years prior to Delight and prejudice. Like the exhibition in Tampere, it was initiated by the LGBTQ community, in this case researcher Kati Mustola (Hiltula 2007, 9). The exhibition was accompanied by a 300-page publication entitled Sateenkaari-Suomi. Seksuaali- ja sukupuolivähemmistöjen historiaa (2007), edited by Kati Mustola and Johanna Pakkanen, which was the first full collection of articles on queer history in Finland. The exhibition covered LGBTQ history from 1600 to the present day and was structured around themes including for example crime and punishment, religion, science, medicalization, the wars, Tom of Finland, invisible meetings, gender diversity, love and marriage, culture, the turning point of the sixties, the AIDS crisis, and the internet.

The exhibition project in Vantaa was impressive in many ways. The museum hired a group of queer researchers to work together with museum professionals on the exhibition manuscript. The president of Finland at the time, Tarja Halonen, agreed to become its protector, and the show was later converted into an online exhibition. But it was not only the exhibition itself and its publication that impressed me: it was also the impact that the process had on the people working at the museum. For many of them, it seemed to be a rewarding learning and unlearning process, and maybe also an affective one. Interestingly, enough the museum decided to include the faces of the museum personnel and of the other members of the theme in the rainbow-colored entrance banner - maybe as a way to show that queer history concerns us all, regardless of sexual or gender identification. In the preface of the book Sateenkaari-Suomi the director of the museum Leena Hiltula also approached the process from a personal perspective:
More than five decades ago in a particular small town in the North, a small girl was playing in the sandpit with seven even smaller boys. They were all good friends. Life was a big adventure. Their worries were small grains of sand. Only one question troubled their minds: how they could turn the girl into a boy. [... The years passed. The girl became a woman, today quite happy that God did not turn their ear to the kids' prayer circle far in the North. But throughout her childhood and youth, the girl had to fight against the demands of the community: girls' clothes, girls' toys, girls' games, girls' manners ... and all the other demands of a girly life. [... ] Maybe this is the reason why the same girl got excited about the possibility of arranging an exhibition on the history of sexual and gender minorities in the museum she is leading. To be amongst the ones telling how criminal, sick, and sinful people became almost equal citizens with the turn of the century. (Hiltula 2007, 9-11, my translation)

My exhibition experience in Vantaa shows how an LGBTQ exhibition project can have an impact not only on its audience, but also on the external experts involved in its creation and on the museum workers.

Much has happened since the first exhibitions on LGBTQ history at Werstas and the Vantaa City Museum. Many historical museums have arranged LGBTQ-themed exhibitions, including, for example, the exhibitions Camp! on queer theatre history in the Theatre Museum (Helsinki 2009), Sealed with a Secret - Correspondence of Tom of Finland on the letters by Tom of Finland / Touko Laaksonen at the Postal Museum (Tampere 2014-2015), and Helsexinki on sexual rights at the Helsinki City Museum (2017-2018). Queer art and LGBTQ themes have, since the early 2000s, become a central part of the art scene, as well as many art museums. Museums around the country have put on larger retrospectives on queer artists and curated queer art exhibitions.
SQS 
Many of these queer initiatives and exhibitions have been created in cooperation with the local LGBTQ community and local and/or national Finnish LGBTQ and other human rights organisations; queer researchers have also often been involved in the planning and production of these exhibitions and audience outreach programmes. The degrees of these groups' involvement the planning process varies. In some cases, the initiative came from the community and the community was consulted (paid or unpaid) throughout the process of the producing of the exhibition; in other cases, LGBTQ experts were consulted only at some points in the process. There are also examples where the museum hired one or several queer researchers to develop the exhibition or to do research for the museum. One example of the latter is the Hotel and Restaurant Museum in Helsinki, which employed Kati Mustola to conduct research on the queer history of bars and restaurants for the exhibition Rakkauden tiloja - Nautinnon nälkä 2017 (Places of love - Hunger for pleasure) (Mustola 2007, 40-44). Many exhibitions and programming events, like memory cafés, have become ways to raise awareness of the invisible histories of the LGBTQ community as well as to collect missing materials and narratives.

During the past ten years there has been an increasing willingness in the Finnish museum sector to show solidarity with the LGBTQ movement. Besides LGBTQ thematic exhibitions, museums around the country have taken part in local Pride events, lent their premises to LGBTQ festivals (like the queer film festival Vinokino 1992- or the cultural festival The Nights and Days of the Tribades 2000-2009), and organized different forms of programming, like seminars and discussions or queer guided tours. In some museums, such as the museums of the National Gallery, the Kunsthalle (Taidehalli), and the Aine Art Museum, the queering of the institution has also involved trainings for museum staff on LGBT issues, equity, and how to queer art/history, run by external experts. Last year, the Finnish National Museum became Pride House for Helsinki Pride, and again in
2020, when Helsinki Pride was due to Covid-19 arranged in September and partly online.

The projects Queering the Museums (2012-2014), Finland 100-In Rainbow Colours (2016-2018), and Queer History Month (2018-), have paved the way for such developments, and might reveal where we may go next. I will discuss these projects at length in the following sections.

\section{A detour via Sweden}

The responsibilities of publicly funded museums in their role as sites for learning and teaching critical thinking have interested me since my first experiences as a guide and guard in the early 1990s. As a former literary researcher, I am interested in narratives and in how and whose narratives are told. What kinds of art, representations, and aesthetics, or what readings and interpretations of history and art, are considered valuable or valid?

In 2012, when I became the Executive Director of Culture for All Service, I got the chance to continue working within the museum field and to help museums update their practices regarding questions of diversity, critical museology, and social justice. Culture for All Service is a state funded agency tasked with supporting the Finnish (especially publicly funded) arts and culture field in handling issues of accessibility, diversity, and equity. The organisation was originally a service within the museum sector. When I started working at Culture for All, it was a part of the National Gallery and located at the Ateneum Art Museum in Helsinki. As a queer person with ten years of experience organizing cultural events for the LBTQ arts and culture festival The Nights and the Days of the Tribades (2000-2009), I saw my new position at one of the most prestigious art institutions in Finland as a great opportunity to engage in institutional queer activism. 
With the help of my colleagues, as well as culture and art professionals such as Katriina Rosavaara (artist and art educator), Kim Amberla (house director and producer at The Finnish National Opera and Ballet) and Riikka Wallin (culture producer), we planned the first steps for a project that later became Queering the museums (2012-2014). A central part of the project was to arrange different kinds of trainings and seminars for the staff of the National Gallery (the Kiasma, Ateneum, and Sinebrychoff art museums) and for other professionals within the museum and archive sector on how to queer their practices and collections. Together with museum staff, we planned an online queer guided tour to the collections of the National Gallery, which we made available in Finnish, Swedish and English. The tour was curated and written by the art historian Juha-Heikki Tihinen. The project culminated with the seminar Queering the Memory Institutions in The Finnish Labour Museum Werstas in August 2013.

The project was inspired by the work of the Swedish Unstraight Museum and the work on LGBTQ art history in the British Museum. ${ }^{2}$ The Unstraight Museum ran an online museum with "unstraight objects" located both in Swedish museums and in private collections, primarily in Europe. It also toured with the LGBTQ historical exhibition Article 1 (a joint exhibition involving several museums) in Eastern Europe. The Unstraight Museum team additionally offered inspiring workshops in queering museums and we commissioned them to host a workshop for the staff of the National Gallery and other museum professionals. At that time, The British Museum had an online queer tour of its collections, which was later turned into the book A Little Gay History: Desire and Diversity Across the World (2013) by Richard B. Parkinson. He was also one of the key note speakers at the seminar at Werstas.

2 The project cooperated with Ulf Peterson and Anna Mazetti-Nissen from the Unstraight Museum and Richard Parkinson from the British Museum.
In addition to these two institutions, I was also deeply inspired by the work on queering museums and history that was being done in Sweden at the time, most notably the queer guided tours that were offered for the first time during Stockholm Pride 2005 by Moderna Museet (Åkerö $2011,13)$. When I started working on queering museums, I had already visited Stockholm during Pride in 2008 and participated in queer guided tours in the Hallwyl Museum and the National Museum, in a lecture by Ingrid Svensson (Head of Division) on queering the collections of the National Library of Sweden, and in a boat tour on which the lesbian history of Stockholm was presented by Ingrid Svensson and the researcher Pia Laskar. My work was also inspired by Swedish projects such as Norm, Nation och Kultur at the Örebro County Museum and : Polysemantiskt digitalt museisamlande (Polysemantic digital collecting (2012-2014) and the JÄMUS project (2012-2013) at the Swedish History Museum in Stockholm. The latter was a project on equity and representation, especially with regard to gender and sexuality, within museums in Sweden. The Swedish History Museum, and the National Historical Museums of which it is a part, have continued to be role models for my own work. The museum has, through several projects, developed its practices regarding queer, intersectional, and decolonized perspectives (Furumark 2013, Uppdrag jämställda museer 2013, Paqvalén 2015, Fernstål, Kolker \& Svanberg 2015, och Larsson Pousette 2017).

Before beginning our project, we needed to find out what Culture for All Service should focus on when it comes to the cultural rights of LGBTQ people. We started by launching a questionnaire for members of the LGBTQ community on their experiences with inclusion and exclusion in the cultural field in Finland, and by creating a public outreach programme for the museums of the National Gallery during Helsinki Pride 2012. Besides a more general questionnaire that was open to anyone, a separate questionnaire on how museums can and should be working with LGBTQ

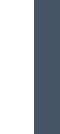


themes was sent out to persons who had participated in any of the three queer guided tours that we offered. The results of the questionnaires were presented in the report Hurjan paljon enemmän queer!" - Seksuaali- ja sukupuolivähemmistöjen toiveita ja kokemuksia taide-ja kulttuuritarjonnasta (2014, “Tremendously much more queer!” - The wishes and experiences of sexual and gender minorities of art and culture offerings). The report consisted of an analysis of the general questionnaire written by Emmi Lahtinen, as well as a mapping of the museum field and an analysis of the museum questionnaire written by me. Based on these findings, we composed 20 suggestions for improving the visibility of LGBTQ themes and the inclusion of LGBTQ audiences in the arts and culture sector.

It was the first time the National Gallery had participated in Helsinki Pride and flown the rainbow flag, as well as the first time (to my knowledge) that any museum in Finland had offered a queer guided tour of its permanent exhibitions. The National Gallery received enormously positive feedback for taking part in Helsinki Pride, especially regarding the symbolic gesture of flying the rainbow flag. Being such an influential art institution, it also paved the way for other museums to follow. The following year, other museums in Helsinki brought out the rainbow flag and organised various different outreach programmes with queer content. Since then, queer guided tours of exhibitions and other LGBTQ thematic programmes have been offered in most major cities, especially during local pride festivals and, since 2018, Queer History Month.

Through my work with the project Queering Museums and the many discussions I had with museum professionals, I realized that many individual museum professionals were eager to reach out to LGBTQ audiences, either through specially designed programming or LGBTQ themed exhibitions, but were restricted by a lack of knowledge on queer theory and LGBTQ history within their institutions. In many cases, this unfamiliarity with LGBTQ history was also accompanied by a shortage of items, photographs, or documents to use when presenting information. But even though there seemed to be a growing interest in the topic especially when it came to the question of attracting new audiences - I was also at times confronted with scepticism, particularly when talking about representations, collections, exhibitions, and curating practices.

Queer and LGBTQ issues, like many other issues related to social justice and inclusion, were often referred to the audience development department, which is also the sector in Finnish museums that has taken an active role in addressing such issues. But it is not only the educators working in museums that have taken initiative in the queering of the museum sector; art education students, researchers, and university professors at Aalto University have also contributed the discussion. First, in 2015, they began offering the course Gender and Art Education, in which the Feminist and Queer in Art (Education) collective was established (Suominen and Pusa 2018). The collective published the anthology FAQ: Feminist and Queer Perspectives on Art Education (2018), which inspired Aalto University to partner with the National Gallery, Culture for All, and the Finnish Museums Association to create an art education seminar entitled Toisin katsottu museo in 2019 (Museums through different lenses, Ateneum Art Museum) (Järvinen 2020, 1-6).

Although many different efforts to address LGBTQ history had already been undertaken between 2012 and 2014, it seemed that queer issues were still regarded as marginal in the context of national history. Museum educators and audience development workers are often the ones bearing responsibility for ensuring diversity in exhibitions, yet they may often be left alone in this process (see for example Laskar 2019, 72, Ahmed 2012 and 2017). Instead, when diversifying narratives and museum practices one needs to find ways to involve the whole staff. 


\section{Queering Independence}

In 2015, the year after the Queering Museums project ended, I was approached by the artist and art educator Katriina Rosavaara, with whom I had collaborated at the start of the project. She was now a board member of the national LGBTQ organisation Seta, and she suggested that we propose a project for the 2017 celebration of 100 years of Finnish independence. We wanted to continue queering the arts and culture sector, and came up with the project Finland 100 - In Rainbow Colours (2016-2018) ${ }^{3}$, through which we - Culture for All and Seta - offered tools, information, and training on LGBTQ history and queer art for professionals in the arts and culture.

The aims of the project were to make LGBTQ history a visible part of the history of an independent Finland, to acquire new knowledge about the history and daily lives of queer people, and to study and exhibit queer art and culture. Moreover, we wanted to pay special attention to accessibility and underrepresented groups within the spectrum of LGBTQ identities. We asked: which roles have LGBTQ people played in our national history, what are our milestones and who are our important pioneers, whose voices and perspectives have been heard, and who is still unheard, invisible, and/ or silenced in the broader queer narrative? The project was granted Finland 100 state funding, and it also received funding from two private foundations (Kone Foundation and The Swedish Cultural Foundation in Finland). In order to make the project as visible as possible, we asked national art institutions and a few other cultural institutions to become our partners.

3 The project was a collaboration between Culture for All Service and Seta. I was the Project Director, Katriina Rosavaara was the Artistic Director, and the Secretary General of Seta, Kerttu Tarjamo, was in charge of the administration of the project. The communication team consisted of Outi Salonlahti and Mira Haataja Culture for All Service) and Eliisa Alatalo. The webmaster of the project was Petja Kauppi (Tekstihuoltamo), who in addition to planning and maintaining the webpages also helped me to edit our blog posts.
The project consisted of four parts: 1) an LGBTQ internet portal, 2) consultations, trainings, and support for professionals, 3) archival cooperation, and 4) events and artistic productions. In the online portal, we collected information and tools on how to queer art practices and cultural institutions, kept a calendar of queer art and cultural events, provided information on archival projects with queer content, and published twicemonthly blog posts by artists, activists, politicians, researchers, and cultural workers. A central part of the project was the support that we offered for free to art and cultural institutions. For example, we provided consultations and support for programming, assistance with exhibition planning, and trainings for personnel. Interestingly enough, we were mainly approached by museums, and most cooperation was with memory institutions (Culture for All and Seta 2018).

Our engagement with different memory institutions in queering memories and practices also included collecting LGBTQmemories. For this work, we collaborated with several archives, most notably the Society of Swedish Literature in Finland (SLS), with whom we also produced the oral history questionnaire Minoritet $i$ minoriteten (Minority in the minority, 26.6.201610.7.2017 ${ }^{4}$, which was directed at the Swedish-speaking minority in Finland. The questionnaire, which I created in collaboration with queer and LGBT researchers Tuula Juvonen, Kati Mustola, and Riikka Taavetti, received 32 responses in total. The project and SLS additionally organised several memory cafés, discussions, and seminars on queer memories in cooperation with other partners. We also produced a pack "memory cards"5 with SLS, the Finnish Literary Society (SKS), and Helsinki City Museum,

4 The answers to the questionnaire can be studied at the archive in Helsinki: https://sls.finna.fi/Collection/sls.SLS+2324 (accessed 10.7.2020).

5 A video presenting the memory cards can be found here: http://www.kulttuuriakaikille.fi/about_us_projects_finland_100in_rainbow_colors (accessed 13.7.2020). 
which could be used in memory cafés and other workshops relating to queering memories. Our cooperation with these archives is detailed in the report Minns du? Vårt queera kulturarv och arkivens roll (Paqvalén 2018).

One of the key benefits of the project was close cooperation with archives, and with SLS in particular. We discussed issues surrounding the accessibility and findability of queer materials, anonymisation and usability, and the division of labour between different archives. Through our partnership, SLS became aware of the cis- and heteronormative practices that would have made it hard for queer subjects to respond to the questionnaire, and hence the project led to some permanent changes in SLS's personal data management practices.

In addition to seminars, discussions, workshops, and other events, the project also partnered with artists by commissioning works of art relating to LGBTQ themes. The commissioned art pieces included the music video Tahdon (I do/I want 2017) by the music group Tero Hetero featuring Hildá Länsman, the community art project Queercache Helsinki (Queerkätkö Helsinki 2017) by the artists Kalle Hamm and Dzamil Kamanger, and the poem Terveisin nimimerkki "Ihmiset ovat hulluja, lesbot vielä hullumpia" (Greetings from the signature "People are insane and lesbians even more so" 2018) by author and poet Helena Sinervo. ${ }^{6}$

6 The music video was a multilingual celebration of the new Finnish Marriage Act (legalising same-sex marriage), which went into effect 1.3.2017. The video included Sámi yoik and singing in Finnish Sign Language, and you could choose subtitles in Finnish, Swedish and North Sámi. It also had a choreography by Henna Helasvuo, and different communities were challenged to celebrate the Marriage Act by performing and sharing the dance on social media: https://www.facebook.com/events/d41d8cd9/tahdon-tanssihaaste-tahdon-utmaning/401893996843284/ (accessed 15.7.2020). Links to all the artworks can be found here: http://www.kulttuuriakaikille.fi/tietoa_meista_hankkeet_suomi_100-sateenkaaren_vareissa (15.7.2020).
In selecting these art projects, we wanted to focus on the diverse realities and histories of the LGBTQ community. We wanted to show that the Finnish queer art scene and LGBTQ history are more than national icons like Tom of Finland (Touko Laaksonen, 1920-1991) and Tove Jansson (1914-2001), and to reveal some of these hidden histories. In the community art project Queercache Helsinki, the urban landscape of Helsinki was approached through the eyes of minorities and subordinated groups within the LGBTQ community. Through geocaches distributed throughout the city, one could learn about being queer with a disability or belonging to different linguistic and/or cultural minorities, about the history of trans people in Helsinki, and about homonationalism and racism within the LGBTQ community and in gay bars.

\section{Celebrating LGBTQ History}

When Finland 100 - In Rainbow Colours came to an end, we - the team behind the project and our project partners - saw it as an opportunity to begin something new. We wanted to continue our collaboration around promoting LGBTQ history and art, as well as to find ways to address gaps in representation and silences within LGBTQ historical narratives. For instance, the trans and genderqueer communities are still largely invisible in the popular narrative of LGBTQ history, as are several other minority perspectives. In the spring of 2018, the project team organized a breakfast for our project partners to discuss how to proceed, and during this breakfast, the idea of arranging a Queer History Month was born.

Currently, Queer History Month in Finland takes place in November. In its first year, the month began on October $20^{\text {th }}$ and concluded on November $20^{\text {th }}$ with events for the International Day of Transgender Remembrance. For the first two years, 2018 and 2019, Queer History Month was coordinated by Culture for All and Seta, but from 2020 on it will 
be coordinated by the newly founded organisation Sateenkaarihistorian ystävät ry - Friends of Queer History - this year in cooperation with the Finnish Labour Museum Werstas. ${ }^{7}$

Unlike in many other countries, where the celebration of Queer History Month has been initiated by the education sector, the Finnish Queer History Month is a direct result of the work in queering memory institutions that has been ongoing since the start of the millennium (Peake 2019). Thus, during its first two years, most of the cultural institutions taking part in Queer History Month have been museums and archives, which during this time have arranged, for example, queer guided tours, discussions, and seminars, and published information on LGBTQ history on their webpages and different social media channels.

Queer History Month has not only raised awareness about hidden LGBTQ histories, but also about the importance of collecting and documenting untold stories and about the responsibilities of memory organisations to do so. During its first year, the researcher Tuula Juvonen and the Labour Archive (Työväen Arkisto) used Queer History Month and its Facebook page as a tool to collect new materials and narratives for its archives through the oral history project Unohtumattomat hetket (Unforgettable moments, Juvonen 2019, 3). The Facebook page has also been a practical channel through which to inform audiences about archival updates. In 2019, the Finnish association for transgender and intersex rights, Trasek, used the Queer History Month Facebook page as a conduit to advertise its own newly created archive in the Labour Archive (a posting 30.11.2019).

7 The web page Queer History Month can be found here: https://sateenkaarihistoria. fi/ - and the Facebook page here: https://www.facebook.com/sateenkaarihistoriakuukausi/?ref=bookmarks
Queer History Month has also encouraged individual LGBTQ activists to share their memories on Queer History Month's Facebook page and elsewhere. One of the most important contributions to the Finnish Queer History Month was by the LGBTQ pioneer Eva Isaksson, who every day in October and November 2018 shared memories, pictures and stories from her youth and activist years, starting in the late 1960s (Isaksson 2018). The following year, she continued to share LGBTQ-related posts almost every day, this time using her own experience as a librarian to provide tips on how to find information on, document, and share LGBTQ history (Isaksson 2019).

Like many great initiatives for queering and diversifying representations of history, this initiative operates mainly without a budget and with the help of many volunteers. The Facebook pages and other social media channels have, in the first years of the Queer History Month, been valuable sources of information, but now the challenge for the team behind Queer History Month is to extend this information outside of bubble of previously engaged audiences, to memory institutions, to other cultural fields, to the education sector, and to the general population - not to mention the challenge of finding funding to coordinate the month. ${ }^{8}$

\section{Towards a More Diverse Narrative}

I have been very happy with the huge amount of interest in queering and diversifying museum praxis that I have seen from museum and archival professionals since beginning my work with Queering the

8 In December 2020, after this text was written, the association Sateenkaarihistorian ystävät (Friends of Queer History) got a huge grant from Kone Foundation for the years 2021 and 2022 for the project "Sateenkaarihistoria näkyväksi" (Making queerhistory visible). The grant will enable the association to recruit a coordinator och pay reserachers.

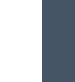


Museum, Finland 100 - In Rainbow colours and Queer History Month. At the same time, however, it has become apparent to me that we need more than just additional knowledge about LGBTQ history in Finland. We, as researchers and professionals within memory institutions, need to pay more attention to what versions of LGBTQ history we are (re) producing and (re)presenting, and to what kinds of stories we collect and how (Paqvalén 2015a-c, Quinn 2020). It is not enough to go beyond the canonized narratives of Tom of Finland and Tove Jansson; we must also strive to approach LGBTQ history from an intersectional, antiracist, and decolonial perspective.

As the historian Pia Laskar writes in her book on queering museums, Den outställda sexualiteten (The Undisplayed Sexuality, 2019), the museum (and the rest of us) needs to re-examine its use of history. By studying the ways in which it uses history, the museum can become aware of the ideals and norms that it, along with the surrounding society, have been reproducing. Instead of applying a modern understanding of gender and sexuality when approaching history or simply adding new layers to the dominant history, museums should analyse and publicise what kinds of historical processes (for example, criminalisation, medicalisation, and religious violence) have produced contemporary understandings (Laskar 2019, 22f). By studying and exhibiting museums' earlier approaches to history relating to sexuality and gender, institutions can demonstrate how the creation of the nation state is linked to the regulation of gender and sexuality, as well as the representation of certain kinds of bodies (ibid 26). Or, as Therese Quinn suggests, the studies of a museum's norms and its approaches to history can also be "entry points for teaching to and about social justice” (Quinn 2020, 69).

We need to ask who we are excluding when writing and presenting Finnish LGBTQ history, and what national narratives we are reproducing in doing so. What does, for example, the current interest in the life and art of Tom of Finland within the museum sector tell us about the national narrative of Finnish history and Finnish masculinity? How can we move past the dominant gay, white, male, and ableist narrative?

Decolonizing and queering museums and national history also demand educational tools $s^{9}$ that are inclusive, critical of social norms, and sensitive towards the diversity of histories and lived experiences within the LGBTQ community. But I am optimistic. The FAQ collective at the Aalto University, the Queer+Crip guided tours developed by the art educators Kaura Raudaskoski and Jemina Lindholm (originally for the Finnish Museum of Photography in honor of Queer History Month 2018), and recent demands by art students in Finland for the addition of "Anti-racist strategies into the curriculum" $(6 / 2020)^{10}$ make me believe that the museum sector in Finland will have a much more diverse future.

\section{References}

Ahmed, Sara. 2017. Living a Feminist Life. London: Duke University Press. Ahmed, Sara. 2012. On Being Included. Racism and Diversity in Institutional Life. London: Duke University Press.

9 For concrete tools see for example Therese Quinn, About museums, culture and justice to explore in your classroom (2020), Pia Laskar, Den outställda sexualiteten (2019), Anniina Suominen \& Tiina Pusa (ed.) Feminism and Queer in Art Education (2018), and the report, Museerna och HBTQ (2015).

10 "Template to include anti-racist strategies into the curriculum," https://equaledu.cargo.site/ (accessed 20.7.2020). See also Black Lives Matter -liike sai suomalaisopiskelijat vaatimaan antirasismin opetusta - Näin vastuuopettajat vastaavat vaatimuksiin. Yle 17.7.2020. https://yle.fi/uutiset/3-11449419?fbclid=IwAR3M2OyEtVg4c8PuqvpCMblOQGthEelPyCYguvKpXA_IlF7IVEB0AZqNdb4 (accessed 20.7.2020). 
Fernstål, Lotta. 2011. Genusperspektiv $i$ museer. En omvärldsbevakning. Stockholm: Statens historiska museum. Accessed 17.7.2020. http://www. sverigesmuseer.se/wp/wp-content/uploads/2011/12/J\%C3\%84MUS_ omv\%C3\%A4rld.pdf.

Fernstål, Lotta, Kolker, Li, and Svanberg, Fredrik. 2015. Polysemantiskt digitalt samlande. Slutrapport. Stockholm: Statens historiska museum. Accessed 17.7.2020. https://shm.se/wp-content/uploads/2016/05/Polysem_rapport_ 02.pdf.

Furumark, Anna (ed.). 2013. Att störa homogenitet. Lund: Nordic Academic Press.

Hiltula, Leena. 2007. "Lukijalle”. In Sateenkaari-Suomi. Seksuaali-ja sukupuolivähemmistöjen historiaa, edited by Kati Mustola and Johanna Pakkanen. Helsinki: Like.

Isaksson,Eva. 2018. Rainbowhistorymonth 2018: links.Accessed 16.7.2020.http:// www.sappho.net/eva/timeline.shtml?fbclid=IwAR0EtqGrzL9V811TSpBMG75CssRES4UoAAD5v8MAM8D_D-pdobA3PUvuO0.

Isaksson, Eva. 2019. Rainbow history month 2019: links. Accessed 16.7.2020. http://www.sappho.net/eva/timeline2019.shtml?fbclid=IwAR2p aJqVq3Xc_zX_XVn4z5Su9sMtu097fhkAYZw_G2mYvd4j1pt4-mz6T0

Jaskari, Ulla, Juvonen, Tuula and Vallinharju, Raini (ed.). 2005. Vaarin paketti ja sateenkaarinappi. Tampere: Työväen keskusmuseo Werstas.

Juvonen, Tuula. 2019. "Nimeämisen mahti. Sukupuolta ja seksuaalisuutta kuvaavien termien suhteisuudesta". In SQS Journal, 1-2/2019, 1-21. Accessed 15.7.2020. https://journal.fi/sqs/issue/view/6115.

Juvonen, Tuula. 2018 [2012]. "Queering Archives and Museums. Raising consciousness about preserving LGBT History in Finland". In Minns du? Vårt queera kulturarv. Ed. Rita Paqvalén, Servicen Kultur för allas publikationer $3 / 2018,24 \mathrm{f}$. The article is based on a paper delivered for ALMS 2012 Conference, Amsterdam, August 1-3, 2012. Accessed 10.7.2020. http://kulttuuriakaikille.fi/doc/undersokningar_och_rapporter/ Minns-du-arkivapport-2018-1.pdf

Järvinen, Jasmin Emilia. 2020. Toisin katsoen, toisin tehden. Toisin katsottu museo ja queer-pedagogiset toimintatavat museoiden yleisötyössä (MA Thesis). Helsinki: Aalto university. Accessed 10.7.2020. https://aaltodoc. aalto.fi/handle/123456789/45274

Lahtinen, Emmi and Paqvalén, Rita (eds.). 2014. Hurjan paljon enemmän queer!" - Seksuaali- ja sukupuolivähemmistöjen toiveita ja kokemuksia taide- ja kulttuuritarjonnasta. Kulttuuria kaikille -palvelun julkaisuja 3/2014. Helsinki: Kulttuuria kaikille -palvelu. Accessed 13.7.2020. http://
www.kulttuuriakaikille.fi/doc/hlbti_-selvitys/Hurjan-paljon-enemmanqueer VALMIS.pdf

Laskar, Pia. 2019. Den outställda sexualiteten. Liten praktika för museernas förändringsarbete. Statens historiska museer. Accessed 15.7.2020. http:// su.diva-portal.org/smash/get/diva2:1357922/FULLTEXT01.pdf

Lindholm, Jemina \& Aapo Raudaskoski. 2019. "Queer/Crip -teemaopastuksista kysymistä ja vastaamasta kieltäytymistä”. In the Cultur for All Service Blog "Puheenvuoroja". Accessed 16.7.2020. http://www.kulttuuriakaikille.fi/ blogi/queer_crip_teemaopastuksista\&d=2020

Lindqvist, Vidar. 2018. Ekenäs. Vasa.

Moksnes, Aslaug. 1996. "Marie Høeg - kvindesaksaktivist og organisator". In Marie Høeg - kvinnesaksaktivist, organisator og fotograf. Horten: Norsk museum for fotografi - Preus fotomuseum, 8-17.

Museerna och hbtq. 2015. Visby: Riksutställningar. Accessed 16.7.2020. http:// www.mynewsdesk.com/se/documents/rapport-museerna-och-hbtqpdf-43656.

Mustola, Kati. 2017. "Kadonnutta kapakkahistoriaa kartoittamassa". In Suomi 100 - Sateenkaaren väreissä. Blogikirjoitukset 2016-2018, Suomi 100 - Sateenkaaren väreissä, 1.2.2017, 40-44. Accessed 17.7.2020. http:// cultureforall.fi/doc/Suomi 100 - Sateenkaaren vreiss/Suomi100sateenkaariblogit-2016-2018_KO-_OSTE.pdf.

Mustola, Kati, and Pakkanen, Johanna (eds.). 2007. Sateenkaari-Suomi: Seksuaali-ja sukupuolivähemmistöjen historiaa. Helsinki: Like.

Paqvalén, Rita, and Rosavaara, Katriina. 2016. "Suomen historian, taiteen ja kulttuurin sateenkaariraita" In Suomi 100 - Sateenkaaren väreissä. Blogikirjoitukset 2016-2018, Suomi 100-Sateenkaaren väreissä,26.4.2016, 4-5. Accessed 17.7.2020. http://cultureforall.fi/doc/Suomi_100_Sateenkaaren vreiss/Suomi100-sateenkaariblogit-2016-2018 KOOSTE. pdf.

Paqvalén, Rita. 2014. "Museot ja sateenkaariyleisö". In Hurjan paljon enemmän queer!” - Seksuaali- ja sukupuolivähemmistöjen toiveita ja kokemuksia taide- ja kulttuuritarjonnasta. Edited by Emmi Lahtinen and Rita Paqvalén. Kulttuuria kaikille -palvelun julkaisuja 3/2014. Helsinki: Kulttuuria kaikille -palvelu, 39-47. Accessed 13.7.2020. http://www. kulttuuriakaikille.fi/doc/hlbti -selvitys/Hurjan-paljon-enemman-queer VALMIS.pdf

Paqvalén, Rita. 2015 a. "Uutta Suomi-kuvaa rakentamassa". Henkilökunta bloggaa 5.11.2015 (the Culture for All blog series), published 5.11.2015. Accessed 17.7.2020. http://www.kulttuuriakaikille.fi/blogg. php?aid=14864\&k=15018. 
Paqvalén, Rita. 2015 b. "Om vårt immateriella kulturarv". Ny tid, 10.4.2015. Accessed 17.7.2020. https://www.nytid.fi/2015/04/om-vart-immateriellakulturarv/

Paqvalén, Rita. 2015 c. ’Normer och historieskrivning”. Nytid, 18.9.2015.Accessed 17.7.2020. https://www.nytid.fi/2015/09/normer-och-historieskrivning/

Paqvalén, Rita (ed.). 2018. Minns du? Vårt queera kulturarv och arkivens roll. Helsingfors: Kultur för alla. Accessed 15.7.2020. http://kulttuuriakaikille. fi/doc/undersokningar_och_rapporter/Minns-du-arkivapport-2018-1.pdf.

Parkinson, R. B. 2013. A Little Gay History. Desire and Diversity across the World. London: The British Museum Press.

Peake, Rose-Mary. 2019. "Sateenkaarihistoriakuukautta juhlitaan toista kertaa Suomessamarraskuussa2019". In the Trivium-TampereCentreforClassical, Medieval and Early Modern Studies blog series. Accessed 15.7.2020. https://blogs.uta.fi/trivium/2019/10/31/sateenkaarihistoriakuukautta-

juhlitaan-toista-kertaa-suomessa-marraskuussa-2019/?fbclid=IwAR2e288 DaYSTzhGHdBkHdGEWVwxZ3jLnSL5soAomCX5d -S50wiKkov-utU

Pilcher, Alex. 2017. A Queer Little History of Art. London: Tate Publishing.

Larsson Pousette, Helene. 2017. History unfolds samtidskonst möter historia : contemporary art meets history. Stockholm: Statens historiska museum.

Quinn, Therese. 2020. About museums, culture, and justice to explore in your classroom. New York: Teachers College Press.

Siltamäki, Tuija, ”Black Lives Matter -liike sai suomalaisopiskelijat vaatimaan antirasismin opetusta - Näin vastuuopettajat vastaavat vaatimuksiin". Yle, 17.7.2020. Accessed 17.7.2020. https://yle.fi/uutiset/3-11449419?fb clid=IwAR3M2OyEtVg4c8PuqvpCMblOQGthEelPyCYguvKpXA_ IlF7IVEB0AZqNdb4

Stuksrud, Brit Connie. Marie Høeg et politisk portrett. Unipub forlag 2009.

Suominen, Anniina, and Pusa, Tiina (eds.). 2018. Feminism and Queer in Art Education. Aalto University publication series ADA 7/2018. Helsinki: Aalto University. Accessed 16.7.2020. https://shop.aalto.fi/p/687-feminism-andqueer-in-art-education/.

Uppdrag jämställda museer. Rapport om regeringsuppdraget att ta fram underlag och utveckla metoder för en mer jämställd representation $i$ samlingar och utställningar. 2013. Stockholm: Statens historiska museum. Accessed 17.7.2020. https://shm.se/wp-content/uploads/2016/05/Jamusrapport.pdf.

Wikander, Ulla. 2018. "Kvinnokärlek, kärleksbeundran och romantisk vänskapskärlek - Vera Hjelt och Victoria Heikel". In Den kvinnliga tvåsamhetens frirum. Kvinnopar i kvinnorörelsen 1890-1960, edited by Eva Borgström and Hanna Markusson Winkvist. Stockholm: Appell Förlag 2018, 105136.

Åkerö, Karl-Emil, Queert var det här! - En studie av fenomenet med queervisningar och en queerkonstpedagogik i Sverige. 2011. (Master thesis) Linköping: Linköping universitet, Institutionen för kultur och kommunikation (IKK). Accessed 5.10.2020. https://www.diva-portal.org/ smash/get/diva2:434762/FULLTEXT01.pdf

\section{Web Pages}

Anti-racist strategies into the curriculum. Accessed 20.7.2020. https://equaledu. cargo.site/.

Culture for All Service. Accessed 17.7.2020. www.cultureforall.fi.

Finland 100 - In Rainbow colours. Art projects. 2017-2018. Accessed 17.7.2020. http://www.kulttuuriakaikille.fi/tietoa_meista_hankkeet_suomi_100sateenkaaren_vareissa.

Finland 100 - In Rainbow colours. Project pages. Accessed 17.7.2020. In English: http://www.kulttuuriakaikille.fi/about_us_projects_finland_100in rainbow_colors. In Finnish: http://www.kulttuuriakaikille.fi/tietoa meista_hankkeet_suomi_100-sateenkaaren_vareissa

Finnish Museum of Photography. The Queer + Crip workshops. Accessed 16.7.2020. https://www.valokuvataiteenmuseo.fi/en/visit-us/workshops/ queer-crip

Friends of Queer History / Sateenkaarihistorian ystävät. Webpage. Accessed 17.7.2020. https://sateenkaarihistoria.fi/.

Preus Museum. "Bolette Berg and Marie Høeg". Accessed 13.7.2020. https:// www.preusmuseum.no/eng/Discover-the-Collections/Photographers/ Bolette-Berg-and-Marie-Hoeeg.

Preus Museum/Flickr."100-Year-OldPrivatePhotos".Accessed 13.7.2020.https:// www.flickr.com/photos/preusmuseum/albums/72157680340928856/ with/32106954754/.

Queer History Month. Facebook-pages. Accessed 17.7.2020. https://www. facebook.com/sateenkaarihistoriakuukausi/?ref=bookmarks

Toisin katsottu museo (seminar webpages). Accessed 17.7.2020. https://ateneum. fi/tapahtumat/toisin-katsottu-museo-seminaari/.
SQS

$1-2 / 2020$ 
Vantaa City Museum. Sateenkaari-Suomi (online exhibition). Accessed 10.7.2020. https://tarinasoitin.fi/sateenkaarisuomi.

Unstraight Museum. Accessed 17.7.2020. https://www.unstraight.org/.

SQS

British Museum. Desire, Love and Identity. Accessed 17.7.2020. https://www.

britishmuseum.org/collection/desire-love-and-identity.

Queer Mirror

Discussions

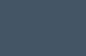

